\title{
Analysis on the Culture Spreading Routes of Macao Music
}

\section{Ga Zhuo}

Art College, Southwest Minzu University, Chengdu, 610041, China

Keywords: Macao culture, Macao music, culture spreading, spreading routes.

\begin{abstract}
As the society continuously develops, the development of all aspects of China has been greatly improved in recent years, especially the economy which is in a state of steady development. However, it is also necessary to pay attention to the development of culture and politics while promoting China's economic development. In addition, in these years, China has developed rapidly under the guidance of the "Belt and Road" strategy, and Macao has also played a self-evident role as an important platform for China and Western cultural exchanges. The period when Macau was governed by foreigners and the sovereignty was returned to China was the time with the most intense and harmonious collision between Chinese and Western cultures, and there was great progress in the music culture of Macao, hoping to draw close the relationship between Mainland China and the Macao Special Administrative Region through the cultural collision between Macao and the Mainland. Since Macao music is an important part of the Macao culture, the spread of Macao music also largely represents the spread of Macao culture.
\end{abstract}

\section{Introduction}

In recent years, in order to speed up the reform of China's higher education system and promote the continuous improvement of the education system, China's education industry has taken significant steps in education equity. Through the comprehensive reform of the education system, the construction of educational equity system has been deepened, and the quality of personnel training and scientific research level have been steadily improved, providing important support for China's economic and social development. Education is the key to national development and national progress, and the foundation of the Chinese dream of realizing the great rejuvenation of the Chinese nation. Therefore, education must be given priority in development. The development of education determines the development of the country. "The wisdom of the youth is the wisdom of the country, and the abundance of the youth is the abundance of the country." The children represent the future of their motherland, while the youth represent the present of the motherland. Hence, the development of university education is closely related to the development of the country. The music curriculum has not been valued by people since ancient times, but in the Macao Special Administrative Region, Macao music is an important representation of Macao culture. Thus, as a university student in Macao, I have made a brief analysis and study of the culture spreading routes of Macao music.

\section{The Macao Administrative Autonomous Region}

The full name of Macao is the Macao Special Administrative Region of the People's Republic of China. It is near Guangdong Zhuhai in the north, and is opposite to Wanchai and Hengqin of Zhuhai in the west. It faces Hongkong across the sea in the east, 60 kilometers apart, and is close to the South China Sea in the south. Macao has undergone the vicissitude and the baptism of history and has formed the unique Macao Administrative Region with the unique Macao culture.

In the history of Macao's development, Macao has been separated from China for some time. In 1553, Portuguese acquired Macao residency. On December 1, 1887, Portugal signed the Sino-Portuguese Conference Protocol and The Commercial Treaty of Sino-Portugal with the then Qing government, taking advantage of the formalities of diplomatic instruments to occupy Macao 
and turn it into a colony. It was on December 20, 1999 that the Chinese government resumed its exercise of sovereignty over Macao through continuous efforts. Macao has been baptized by European civilization for more than 400 years. The coexistence of Eastern and Western cultures has made Macau a unique city, with a large number of historical and cultural relics left including music with unique styles. Its historic city of Macau officially became the UN World Cultural Heritage on July 15, 2005. Since the return of Macao to Macao, the economy has grown rapidly and is more prosperous than in the past. After the integration and collision of Chinese and Western cultures, Macao culture has gradually become famous in the world and is a successful example of one country, two systems. In the 21st century, Macao is an international free port, one of the world's most densely populated areas, and one of the world's four largest casinos. Its well-known light industry, tourism industry, hospitality industry and casinos have made Macau a long-lasting city, and it has become one of the most developed and affluent regions in the world. The developed and prosperous Macao City has also brought about better development of Macao's culture.

\section{Introduction to Macao Culture}

Macao is a successful example of China's "one country, two systems" and has unique geographical advantages and historical background. Therefore, Macao culture not only reflects the profound meaning of China, but also represents the fusion of Chinese culture and Western culture supplemented by Portuguese culture. It is a diversified and inclusive culture based on Chinese culture and compatible with Portuguese culture. As Chinese residents continue to stay in Macau in hundreds of years, Chinese traditional culture has also been brought into Macao, forming the main culture of Macao Chinese, especially in music. The tradition of the Chinese nation is perfectly inherited. The essence of the perfect fusion of Western culture has formed its unique Macao music culture. The biggest feature and contribution of Macao culture was the establishment of a trade center in the 16th and 17th centuries, and the establishment of the Macao International Music Festival, which represents Macao culture. The Macau International Music Festival has a wide variety of programs, including Chinese music, symphony, chamber music, opera, small concerts, even musicals, ballet, jazz, drums, concerts, etc., and the artists from all over the world, among them Most of them are in mainland China and Portugal. The Shanghai Choir, Symphony Orchestra, Central Opera and Ballet Theatre Symphony Orchestra performed in Macau more than once during the festival. Therefore, the Macao music culture has greatly promoted the exchange and collision of Eastern and Western cultures, making Macau music a symbol of Macau today.

\section{Analysis of Macao Music Transmission Path}

\subsection{Improvement of the music teaching system in Macao}

It is understood that in the current university education in Macao, the music major is not very popular, and the music appreciation situation is narrow. The study of music, especially the study of music by students is limited to the book content, and the teaching of music cannot be limited to books. The content above not only receives the intuitive feelings of the text, but also the essence through the phenomenon, the deep thoughts, the commonality of different things, and the broadening of learning thinking. In particular, Macao music that integrates Chinese and Western cultures has higher requirements for teaching music and deeper rumors. Therefore, in the teaching process of Macao music, the first thing we need to do is to understand the students' inner feelings. As the saying goes, interest is the best teacher. Whether it is in the Mainland or in Hong Kong, Macao and Taiwan, the meaning of this proverb will not be changed. This course of music allows students to enjoy music and enjoy the charm of different music in the music class. It can temporarily ease the intense learning atmosphere of students, and at the same time promote students' focus and input on the next course. The music played can be a pure Chinese song, or a popular song with a Western flavor, allowing students to feel the difference between the two kinds of music and to create their own style of music 
culture.

\subsection{Rational use of the Macau International Music Festival}

If you want to make Macau's music culture known to the world, the Macau International Music Festival is a good point to spread. The Macao International Music Festival has a variety of programs, such as Chinese music, symphony, chamber music, opera, small concerts, musicals, ballet, jazz, drums, concerts, etc., and the artists from the performances come from There are many places in the world, including China and Portugal. During the Macau Music Festival, we can also take this opportunity to let more people know about Macau's music culture. In order to let Macao's music culture spread to all parts of the world, the development of the cultural industry must be highly valued by the government, strongly supported and persevered, and strive to promote. It can be said that the Macao Music and Culture Festival is an important part of Macao's music culture. This is a rare event from the beginning of the Macau Music and Culture Festival. When it comes to people in recent years, we can see that Macao's music culture is increasingly known to people around the world.

\subsection{Audiovisual film and television and publishing industry development of Macao music}

Cultural resources are an important part of social development. They are also an important structure and basic condition for the development of cultural industry. As an important part of Macao culture, Macao music has also received the attention of the government. It is an important event for the development of the people of Macao Administrative Autonomous Region to develop characteristic cultural resources and create a music and cultural industry with the characteristics of the Macao people. Based on the music culture with Macao characteristics, from the cultural tourism, art industry, audio-visual film and television industry, publishing industry, etc., we have made targeted research on the problems arising in industrial development. I hope that through the development and research of audiovisual film and television and publishing industry, more people can understand the unique spirit of Macao music. For example, for the history of the development of Macao music, you can make a film into related movies, let more people know the history of Macao music, or invite Macao local singers to hold a concert tour to let more people hear Macao music. Let Macao singers record the albums, so that more people can listen to music with Macao characteristics anytime and anywhere to speed up the spread of Macao music culture.

\section{Talking about the Prospect of the Culture Spreading of Macao Music}

Culture needs inheritance and culture needs development. In order to better inherit Macao music culture and further inherit China's excellent music and cultural traditions, we need to constantly strengthen cultural self-confidence and excavate these unique regional cultures. And elucidation, promote creative transformation, innovative development, let the culture and the drizzle infiltrate the lives of the masses, and then arouse the recognition and enthusiasm of the grassroots for Chinese culture. From the children, from the youth, from the grassroots to tell the Chinese story, send out the Chinese voice, and create cultural confidence with Chinese characteristics, Chinese style and Chinese style. As an important part of Macao culture, Macao music not only has the national music representing Chinese traditional culture, but also the essence of Portuguese Western music, forming a unique Macao music culture. Therefore, the development of the Macao Special Administrative Region is inseparable from the inheritance of excellent traditional culture, so we must constantly propose improvements to strengthen the protection and development of Macao's music culture. On the one hand, the government must constantly make policy adjustments in this regard, and actively promote the culture of Macao music in the Mainland or abroad through online media and other means, and call for people to carry out extensive publicity and development of Macao music. Music and Macao culture are properly protected and passed along. On the other hand, the government should actively encourage people from all over the world to participate in the Macau International Music Festival, so that people from more countries can learn about the Macau International Music Festival and the development of Macau's tourism industry can be promoted, thus effectively improving the 
inheritance of the music culture of the Macau Administrative Autonomous Region by people in modern society, further promoting the construction of the cultural soft power of the Macao Administrative Autonomous Region and improving the overall national strength and international status of the Macao Administrative Autonomous Region.

\section{Conclusion}

It is understood that there are many music lovers in Macau. Meanwhile, music also brings joy and happiness to people. For example, good music can relax our body and help us relieve stress. Music can stimulate the brain and activate brain cells as well. Appropriate music stimulation can greatly help the brain's activities, and even achieve the effect of preventing its aging. Music can help to sleep, improve immunity, increase nerve conduction rate, enhance memory and attention, and make people's body and mind get moderate development and liberation. Therefore, Macao people who love music are good both physically and psychologically. Macao music has already formed a unique music style that represents Macao's special culture through the collision and integration of Chinese and Western music cultures, so Macao's music needs to be known by more people in the world as well as its culture. This paper briefly discusses the spreading routes of Macao's Administrative Autonomous Region and its music culture, and summarizes two major points: First, start with music education. In order to spread the music culture of Macao, most of Macao locals should have a simple understanding of Macao music, because our leader once said: "To strengthen the country, we must first strengthen education". This view is equally applicable to Macao as an administrative autonomous region of China. Second, use the Macao International Music Festival to spread the Macao music culture, because the music festival is valued by people who love music in various countries. The Macao government should lay emphasis on the Macao music festival, which will play a very important role in the spreading of Macao music.

\section{References}

[1] Liang Xiabin. Music Teaching Should Pay attention to the Cultivation of Students' Individual Interests, Guangxi Education, 2007, (34).

[2] Zhao Huiying. On the Cultivation of Music Interests, Art Education, 2006, (03).

[3] Yi Xiping, Chen Wenpei. On the Cultivation of Music Interests from the Perspective of Psychology, Journal of Qujing Normal University, 2004, (04).

[4] Feng Changchun. Some Investigations and Reflections on the Music Appreciation Course in High Schools, Music World, 1995, (04).

[5] Zhan Jing. On the Cultivation of Students' Interests in Music Teaching, Science \& Technology Information (Academic Edition), 2006, (09) .

[6] Dai Dingcheng. Music Education in Macau, Macau: Macau Daily Press, 2005. 